\title{
Gail Gerhart interviews Robert Mangaliso Sobukwe (1970)
}

Robert Sobukwe (1924-1978) grew up in Graaff-Reinet, attended Healdtown, and graduated in 1949 from Fort Hare where he had a distinguished academic record and showed promise as a public speaker. He became a teacher in Standerton, and later taught African languages at the University of the Witwatersrand in Johannesburg. In April 1959 he was elected president of the Pan Africanist Congress at its founding. Jailed in the aftermath of the PAC's anti-pass campaign in March 1960, during which the Sharpeville massacre occurred, Sobukwe spent nine years in prison, six of them in solitary confinement on Robben Island. After his release in 1969, he was denied an exit permit to take up employment offered to him in the United States. He was restricted to Kimberley, banned from meeting with more than one person at a time, and from contributing to the preparation of any publication.

This interview was conducted by Gail Gerhart, at that time a graduate student at Columbia University in New York City. It took place during the mornings of August 8 and 9, 1970, in a rental car on the outskirts of Kimberley. Because of police surveillance and Sobukwe's banning order, no notes were made until after Sobukwe was no longer present, when the notes below were spoken onto a tape recorder by the interviewer. The notes are verbatim only where indicated by quotation marks, and otherwise reflect the interviewer's best recollection of what was said. This interview has been made available on condition that proper acknowledgment is made for use of any of its contents. The original USAmerican spelling is maintained in this interview. 


\section{Gail Gerhart (GG): When did you first become interested in politics?}

Robert Mangaliso Sobukwe (RMS): My first awareness of politics was in 1948 at Fort Hare when I took a course in Native Administration. This course was taught by Ntloko, and there was a text by Hanley(?). I had always known most of the facts as such, for example that Africans had three representatives in Parliament, but up to then I had merely accepted these as facts which one had to learn, to memorize, without thinking of their implications. During this course I began to realize what the reality was, for example that these white MPs [Members of Parliament] had no effect on policy, in spite of the fact that they were eloquent speakers. Ntloko was an AAC [All African Convention] man, and the AAC was very influential at Fort Hare in those days. Most of us agreed with what the AAC stood for, except we didn't like the fact that they were not African nationalists. The [Afrikaner] Nationalists' victory in 1948 helped politicize me.

[Lecturer] Godfrey Pitje and I started the Youth League at Fort Hare. Pitje was the one who had had a connection with the early Youth League in the Transvaal. He was our link. He had known [Anton] Lembede.

\section{GG: Did Pitje give you documents drawn up by the early Youth League, or statements of Lembede?}

RMS: No, we never saw these. We drew up our own documents. It was all conveyed to us through conversation and discussion.

\section{GG: Did you favor the efforts in the late 1940 s to reunite the AAC with the ANC?}

RMS: Yes, very strongly. We wanted total unity, though; not a federation. We always felt that federations were inherently weak. This was also the case with the Africanists later when [Josias] Madzunya's group wanted to federate with us. We wanted unity, not a federation.

The ideas of the AAC were good, but we knew they could never be counted upon to act. They believed that no action could be launched until the people had been "properly educated." Only they could say when this had been achieved. We felt this would take forever, and anyway that it was only through action itself that the people would come to understand fully the nature of the struggle.

\section{GG: What was your role at the time of the 1949 Program of Action?}

RMS: The Program of Action was drawn up "at Fort Hare by Pitje and myself." Of course 
Z K Matthews was also there and was consulted. Our draft was then taken to the Cape ANC provincial annual conference in Queenstown in June 1949 where it was approved by the conference. The province was then under the leadership of [Rev James] Calata and Matthews. Both at Queenstown and at Bloemfontein I spoke in favor of the program as we had drafted it.

\section{GG: Did people come to Bloemfontein from the Transvaal and other provinces with other drafts for consideration?}

RMS: Not as far as I can remember. I don't recall any other versions offered, from the Transvaal or elsewhere. The final version adopted was ours, except for one clause which was inserted at Bloemfontein, the clause calling for a one-day strike. Ironically, I think Calata proposed this clause.

We went to Bloemfontein from Fort Hare feeling that [ANC president, Dr A B] Xuma was still our man. We thought he was a good leader and could be kept if he could be "tied" to a program. He was in the habit of acting very independently, on his own judgment. We went there prepared to support him, but found to our surprise that the conference rejected him.

\section{GG: Was there opposition to the program from the left?}

RMS: We went to Bloemfontein expecting that they would oppose it, but in fact they didn't oppose it; they supported it.

\section{GG: Did you feel that the 1952 defiance campaign followed correctly from the program of action?}

RMS: No. By this time the Program was already being compromised. The struggle was always to bring the ANC back to the Program. During the 1950s it strayed far away. If the Program had been followed we would all be living different lives today. Deviation began with the strikes in 1950. These were concocted by the left wing. We felt that they had nothing to do with us but were merely protests at the banning of the Communist Party. A split was already beginning in our ranks; the Youth League was on the decline. Some were going over to the Communists.

The main thing we didn't like about the Defiance Campaign was the leadership role taken by Indians and whites. It was a lesson we had learned, that whenever these groups were involved in any action, you had the Africans just "taking a back seat," sitting back and letting these people run things. We felt this had to be overcome and that Africans had 
to learn to take the initiative, to do things for themselves. I recognized there were some non-Africans who fully identified with us and were prepared to sacrifice, but as a matter of principle we couldn't let these people take any part because of the bad psychological effect this had on our people.

One reason some Africans welcomed Indian and white support was that as of the time of the Defiance Campaign it became clear that campaigns would always end in everyone needing a lawyer and money for defense. This increased dependence on non-Africans.

When the split began, we knew that Sisulu had gone over and Mandela had gone over. Tambo, we knew "was resisting". We saw this happening in the Youth League. I myself was national president - no, national secretary. Pitje was president. We were elected in December 1949 at the ANC conference. We saw this split happening, but we were just too weak to prevent it.

When J B Marks ran for President of the Transvaal, we were opposed to him. We backed Selope Thema. We knew that if Thema became president, we - the nationalists in the Youth League - would be able to use him to promote our line. But Marks was very popular, partly because he was well known from the 1946 mine strike, and he won. It didn't make sense to most people to oppose him simply because he was a Communist [Party member].

\section{GG: What was it about communism that attracted Africans of your generation?}

RMS: First, it was "the militancy" of Communists. They had a press that vigorously aired the grievances of Africans, exaggerated them, in fact; just as the Post and The World nowadays exaggerate murder and rape. This impressed us.

Secondly, we knew that if someone was a Communist [Party member] it meant he had no color prejudice. He accepted you as another human being, this you just knew. A Communist would listen and frankly criticize what an African said, treating his arguments on merit, showing where they were weak. The liberals were different. They never wanted to risk hurting anyone's feelings, so if they were critical of what an African said, they'd just keep quiet, and that was no help to anyone. But we knew the Communists would never accept nationalism, and that is what we held against them.

The split began around 1950, and it centered in a way around the competition between Marks and Thema. It was hard for us to attack Marks. The people didn't care that he was 
a Communist; he was popular and a good speaker. He was a strong leader and a very "hard working" man.

At this time I was in Standerton but I was coming frequently to Johannesburg, as early as 1950. We had the Bureau of African Nationalism circulating our ideas. I received the Bureau's sheets from Leballo, and I contributed pieces. I don't remember actually meeting Leballo until 1954. Cape people were also involved in the Bureau.

By 1950 the Youth League was declining, being absorbed into the ANC, and the split was starting. The League no longer had the strength it had had in 1949. You had people like Duma Nokwe who had gone over. We knew he was attending Communist meetings, of the "Communist Youth League." They were operating here and there, and at St. Peter's School.

One issue where we differed strongly with the Communists was on the question of boycotting the Advisory Boards, parliamentary elections and so on. They opposed the boycott because they were sometimes able to get their people elected. This was in direct contradiction to the Program of Action. [Elias] Moretsele, for example, was on an Advisory Board. But we had the people with us on this question. They had seen the uselessness of these bodies. But Congress just "dilly-dallied" on the issue.

According to [Ntsu] Mokhehle, the Communists have used the same type of technique in Lesotho, tactics of infiltration. They've tried to get people into positions of influence, by hard work.

\section{GG: Why do you think some Africans were attracted to the left while others weren't? Was it circumstances, personality, or what?}

RMS: It was mainly a matter of "contact" between these people and Communists, in Johannesburg. Firstly, there was the appeal of Communist philosophy; it's a doctrine that no one can object to philosophically. It's for the poor, it's against wealth, it's for equality. No one can quarrel with the kind of society communism holds out in theory. We ourselves didn't so much oppose Communist philosophy, but we could see in the states that were Communist that the ideal couldn't be put into practice, in Russia and China. First you had the party - supposedly the dictatorship of the proletariat, but really the dictatorship of the party. Eventually, as with Stalin, this became the dictatorship of the leader, one man. We could see this was the case. Milovan Djilas confirms it in his book, The new class.

But it was hard to object to the principles of communism in the abstract. Once a person was invited to the homes of these white Communists, he couldn't then raise any 
objections to Communist practice, in Russia for example, because it would have seemed impolite or irrelevant. Such Africans got to know these whites as friends, and participated in their discussions. And one could always be sure that these whites were unprejudiced, and ready to accept Africans on their individual merits. This was the immediate thing; the reality of Russia was far away.

\section{GG: When you were at Wits [University of the Witwatersrand], you and other Africanists had the opportunity to accept such invitations. Why didn't you?}

RMS: We had already seen too many people corrupted; we had their example to learn from. It began as early as1950. So we declined the invitations, and eventually our sympathies became known and we weren't invited anymore. We were shocked at what had happened to staunch fellows like Mandela, who were so opposed to communism at first. He just went over. We felt he "lacked backbone." In the case of Sisulu, everyone could see what had happened. While he was secretary-general, there was one period of about six months when the ANC was so poor that the phone and electricity were cut off in the office. These Communists from the Indian Congress - [Yusuf] Dadoo and [Yusuf] Cachalia - came and supplied the ANC and Sisulu with money. Also Sisulu's business was in trouble. You couldn't blame him for being grateful to these men. Sisulu even said this openly himself to us, that what else could he do?

\section{GG: Did you consider Sisulu an intelligent man?}

RMS: Well, I don't think so really. He was very hard-working and devoted to the ANC, but he lacked education, and this made him defer to the opinions of more educated people. When he got into discussions with more educated people, he would usually just accept their judgments.

Mandela was one man I never really knew personally until I was already in prison. We were never friendly, although I had heard him address meetings and had met him. He is a very "arrogant" man. He lacks a common touch. I remember him at one meeting around the time of the Defiance Campaign. People had gone there still undecided if they were going to participate. Mandela got up and said very peremptorily, "All those with us, come forward; all others get out." And most people just got out. They were put off by his manner. Mandela was strong among the leaders, although we always recognized Tambo as superior in intelligence. Mandela had a way of attacking people very viciously if they disagreed with him, and were a "smaller" person than himself. He could reduce them to a "shriveling" mass, then he would "pat them on the head and draw them to him," and thereafter they would be his men, always deferring to him, looking up to him. If he came across 
any man who wouldn't look up and defer to him and acknowledge his superiority (e.g. myself, implied) then he wouldn't have anything to do with that person. Mandela could always attract weak people; but he could never get on with another strong person. In any relationship, he had to dominate. But he was an engaging person. He could always crack a joke, make you laugh; he always had a story to tell. But I was never friendly with him.

Tambo was closer to our point of view, but his loyalty to the ANC was just too strong. Of course he already had a high position in the ANC, from the earliest days, so he felt obliged to defend it. Tambo and Mandela never got on well together. Tambo is a much quieter man, but very intelligent.

\section{Gail Gerhart (GG): Is it true that Mandela was betrayed by the communists because he came back from his Africa tour rejecting multiracialism?}

Robert Mangaliso Sobukwe (RMS): We could never get a straight answer out of him in prison about this. We did get the idea he had had some falling out with "Ruth First and that group". He was very impressed by what he saw in Africa. He met Oginga Odinga and was impressed by him; he met Kenyatta, waving his flywhisk. These people affected him more than the white leaders he had met. But it was clear that Mandela was a Maoist. We got to know this in prison. I don't know if he finds Mao especially appealing because he is a non-white. Mandela was very well read up on Mao. In a sense, though, he is really a Titoist, that is he believes in some reconciliation of communism and national peculiarities. Philosophically, Mandela has always been an "opportunist," going from one theory to the next, taking out what seemed most likely to be impressive to other people, most likely to boost his own prestige. Oddly, he also showed tendencies in jail of being a tribalist. He used to wear a ....... (some article of Xhosa attire?) We used to criticize him for this.

\section{GG: What did you mean when you said that all communists in South Africa were "quacks?"}

RMS: I meant that they were only intellectual communists. The type of lives they led the whites and Indians - precluded their being considered practicing communists. They had too many privileges. They were wealthy and they used and enjoyed their wealth. And deep down they actually believed in the perpetuation of these inequalities. Communists in South Africa "have never been really revolutionary." They are merely communists and revolutionaries intellectually. They were always well-read on communist theory and literature, and could recite it back at great length. But none of them were willing to materially come down to our level, or to accept the possibility that roles might someday be reversed. 


\section{GG: Would most communists have been willing to accept an African government?}

RMS: No, they would have always opposed it, opposed any nationalistic government. We Africanists made a point of reading Lenin and Marx to learn the vocabulary of communism. Then we used their terminology to support our own arguments. This had a way of really disarming them.

\section{GG: What was your role in the Defiance Campaign?}

RMS: I had spoken publicly in its favor. Once Tambo came to Standerton and we addressed a meeting together. "I didn't launch." We had received instructions from Johannesburg to wait and we were about to launch within a few weeks at the time when the Campaign was called off. I had in the meantime been dismissed from my post for speaking out.

The campaign was called off because the leaders got cold feet. When these laws were passed, it became clear that they weren't actually prepared to make sacrifices.

\section{GG: When you first came to Johannesburg from Standerton, did you want to get involved in politics?}

RMS: When I got to Johannesburg I met P K [Leballo] and his group. I felt that we were up against strong forces and we shouldn't make ourselves targets until we had built our strength. P K was already getting expelled and so forth. I didn't want to get expelled. But "P K was a fighter!" (said with admiration). He was always for barging ahead. He could never hold his tongue when he was provoked.

This group had begun The Africanist and they invited me to be the editor. Peter Molotsi had been the editor up to then.

In trying to put our point of view across in Congress we were very frustrated because of the leadership situation in the ANC. By this time the real leaders were banned and couldn't speak openly. Therefore we couldn't directly attack them personally, and there was no way they could personally reply to us in public. We knew. however, that it was they who were responsible for the course of events in the ANC. While these banned men were behind the scenes, men of much lesser calibre - total "fools" - were actually in the leadership positions in Congress. We had no respect for any of these people; yet there was no point in personally attacking them, because they were simply carrying out 
instructions from the banned leaders, saying what they'd been told to say by the big boys. They tended to be dogmatic and there was no point in trying to engage them in argument. Our tactics in the face of this were to try to use every meeting and conference to speak directly to the people, to "hammer home" our "line" with all the persuasiveness we could. Pretty soon they got wise to this and began to exclude us from conferences.

But we were up against a situation that has always existed in South Africa, namely that the masses will automatically follow a leader or organization that they have a loyalty to, without thinking about the wisdom or weakness of particular policies they are told to support. This is particularly true of the women. Oh, the women!

"We knew that our numbers were small" and that it would be hard to put our views across. I was ANC chairman in Mofolo [in Soweto], and their tactic there was to have their own man with a rival branch, and when conferences came they would recognize him as a delegate instead of me.

We didn't put much faith in [ANC president Albert] Lutuli. He was a gentle old man, but he didn't have much political sense. He was politically naïve. I don't suppose there was ever a speech of Lutuli's delivered at a conference that was in the original form in which Lutuli had drafted it. Leaders like Mandela had a "cynical" attitude to Lutuli.

At one ANC annual conference - probably 1955 where the Freedom Charter was debated - there was a violent fracas. Calata was presiding. The Charter was finally shelved on the grounds that it was contrary to the constitution of the ANC to adopt it. They postponed it and then called a special conference the following April to adopt it. The conference was actually meant to consider another issue - passes for women - but this wasn't discussed. People were just brought there to ratify the Charter.

The people running the ANC by this time were a very mediocre lot. One couldn't engage them in argument because they didn't themselves understand the policies they were supposed to defend. Just as in the earlier days, we felt the ANC was only reacting to moves made by the government. It had abandoned the Program of 1949 altogether. Our aim was always to bring the ANC back to the Program of Action. We would be living different lives today if the ANC had stuck to that Program. 


\section{GG: Do you think there was any element of cynicism in the ANC regarding the alliance? A belief that it was tactically wise, practical in terms of getting money and organizational help (while leaders were actually nationalists at heart)?}

RMS: No, they were actually convinced of the correctness of multiracialism.

\section{GG: Was the Freedom Charter attacked more as a symbol of the Alliance or because of what it actually said?}

RMS: We objected to the whole thing. Raboroko wrote an excellent rebuttal to it, emphasizing the impossibility of whites and Africans being considered "brothers" in South Africa. We knew that every white person - no matter how sympathetic he was to us - benefited from the South African set-up, and enjoyed privileges based only on color. Whites would say to us, "What can I do? Give up my salary? My house?" And what could we say to them? We had no answer for them, but we knew they could never be seen apart from the material situation.

The Freedom Charter said something ridiculous about how the land has been taken from us, we blacks and whites together. But how could they try to avoid the issue of whose land had been taken by whom? They were trying to gloss it over.

Sometimes when I discussed these problems with Benjie [Pogrund] and Patrick Duncan [anti-Communist white sympathizers] we tried to come up with another word, some new term that would crystallize the idea of non-racialism as opposed to multiracialism. We could never think of a good word, other than "nonracialism" itself. We hated the word "multiracialism."

We knew that the Freedom Charter wasn't actually drafted at the Congress of the People. It had been drafted by "Slovo and his circle." People just arrived there and found the thing already printed up.

\section{GG: Why did you believe the Africanists would be able to prevail eventually?}

RMS: We thought this for a long time. At the time I came to Johannesburg there was still no feeling that there might have to be a break and a separate movement. 
Another thing about the ANC that we objected to strongly was the Consultative Committee [of the Congress Alliance] with its system of representation. Only two from the ANC and two from each of the other, much smaller, groups. In any arrangement like this we knew the ANC would be taking a back seat even though it represented millions.

\section{GG: Why did the Africanists try to run Madzunya for Transvaal president in 1958?}

RMS: I don't recall the exact sequence of events here. Madzunya was never part of the inner group in the Africanist movement. He had a following of his own. He had been important at the time of the 1957 bus boycott in Alexandra, and he was a critic of the ANC. He wanted to be with us. But he was uncontrollable, like a "wild steer." He was actually backed for this election by an odd collection of people like the late $\mathrm{P} Q \mathrm{Q}$ Vundla and [journalist] B Legwate, people who sympathized with us but were only on the periphery of our movement. We didn't accept them as members, but they suggested that Madzunya run, and we thought he could be "used." We thought we could let him draw the fire of the enemy, and use him to test our strength.

Madzunya was not an educated man. He probably didn't grasp the full import of our philosophy. His thinking was rather "primitive" - he wanted to put spears and shields on our flag! (laughter). He didn't trust middle class educated people like the rest of us. He said such people would never be able to suffer and sacrifice.

\section{GG: What was [A P] Mda's position during this time?}

RMS: Mda was one man we have always admired for his "brilliance" and clarity of thought. He has a great gift for language, a way of using words to express ideas with complete clarity, He can "untie mental knots." One could go to him with any problem, and he would analyze it for you, untie it. We tended to always accept his advice on any subject. Compared to Mda, all of us were "political babies." He had been around much longer. He had more knowledge of the South African situation than anyone. He had read very widely. He knew much more about communism than we did, for example. We could always go to him and get a clear "analysis of the situation." That was his great strength. He could also advise on action and organization. He advised us to organize secretly, through cells, to "build up our strength before coming out in the open." He was very much influenced by the writings of Lenin. 


\section{GG: Did he actually cite Lenin?}

RMS: Yes. We were always amused at how he could oppose communism so strongly, yet use the principles of Marxism to prove his case for nationalism (laughter). In the fights with the AAC [All African Convention] it was always A P who could outline to us the line of argument. I first met him when I was at Fort Hare.

But A P was bitterly against the breakaway. He told us how all the other breakaways had failed - [Paul] Mosaka's ADP [African Democratic Party] and so on. He also disagreed with us when we decided to launch. He wrote me a critical letter, saying that our view of the situation was too "apocalyptic."

In the days of the Africanist movement our nationalism was mainly "emotional." We needed A P to help us intellectually to work out our position. [NB. He later uses identical terms to explain his own position vis-à-vis Leballo in 1954-55].

\section{GG: Many people seemed to have hero-worshipped Mda. Did you share this feeling toward him?}

RMS: This was certainly the case. Even P K felt this way toward Mda. Myself? Well, I don't know. A.P. is a great student of revolution. At our conference of September 1959 he kept pointing out how Mao hadn't done such and such a thing in China.

Around the time of the break I was going down to the Cape - was I going to Grahamstown to work on my riddles? - and I went by Engcobo to look for Mda. I forget who was accompanying me. We didn't find him home. I don't recall exactly when this was. But we decided we would just have to go ahead with what we were doing without consulting him. Even P K said this, and he was a great admirer of Mda. But A P wrote us to say he disapproved of the break.

\section{GG: How did you feel about the fact that by 1959 paths had diverged with mda?}

RMS: I suppose we regretted it, but by this time the situation had changed. The younger men didn't know A P; he wasn't widely known. He was only known to the early Youth League men. So it wasn't so widely discussed. We knew A P was busy doing his law, and that physically he was not strong. And we knew that he himself would never go to jail. 


\section{GG: Did you feel he was out of date? Out of touch?}

RMS: Yes. We just had to go ahead without him. We still respected him, but his opinion wasn't sacrosanct any longer. We still saw him as the repository of our ideas. I think it was 1957 when I went to Engcobo to look for A P In September 1959 we got him to attend our NEC [National Executive Committee] meeting in Bloemfontein. He was quite impressed with our success at that time, even though we didn't yet have the 100,000 members we had predicted. He was impressed with the success of our Inaugural Conference. He didn't attend that, but he was in Johannesburg at the time. He gave us a wonderful talk that night at Bloemfontein on organization. A P had a power over words. He could manipulate words so that they said more than just their surface meaning. Like the slogan of the Youth League - Africa for Africans, Africans for humanity, humanity for God.

\section{Gail Gerhart (GG): Who formulated the later slogan that anyone who owed his first loyalty to Africa and accepted the rule of an African majority would be considered an African? Was the ambiguity of this intentional?}

Robert Mangaliso Sobukwe (RMS): I suppose it was (laughter). This came from the earlier Youth League slogan, from the first clause of it - Africa for the Africans. That was the part that had always received all the attention. This was our formulation.

\section{GG: YOURS?}

RMS: Yes. It was so funny, because by this time Benjie and I were already friends, and he used to really get after me about this one. Also the late Patrick Duncan. They argued that you couldn't promote exclusivism then hope that tomorrow the people you had organized exclusively would turn around and begin recognizing these other non-Africans as Africans. I could see this argument, but I still felt that history would bear us out and that we were choosing the correct course.

We knew many people agreed with us. When we were setting up the PAC, we tried to persuade [Z K] Matthews, for example, to come with us. But we couldn't get anywhere with him. He was too much an ANC man, although we knew he agreed with a lot of what we were saying. [This a little wistfully as though they'd been disappointed or hurt by Matthews' reaction.] But regardless of what our strength was, we had to stand on our principles.

I know it is true that there were times when we simply were not clear in our own minds of how to deal with the situation. [These are not the exact words; but the idea was 
definitely expressed]. This is why sometimes our slogans were misunderstood or ambiguous. This perhaps reflected confusion in my own thinking, but I was always certain of certain basic principles.

It was hard to fight an established organization like the ANC. I can remember when I gave a speech at Fort Hare in 1948 to the graduates, I told them to always make politics part of their lives. I said if you're a doctor, don't just treat the patient for his physical ailment, also send him down to join the ANC. If you're a teacher and you see your children coming to school nearly naked in winter, tell yourself, and tell the parents, what the cause of that is. Link it to politics. This was the kind of spirit we had in those days.

Being up against the ANC was like being up against a church. It was like a religion to its followers. Your father had belonged, so you belonged. People like Z K Matthews knew the appeal of the ANC in this way, and would never leave it. It had the tradition and aura of a church.

In the days of the early Africanist movement we had cells in the Rand area, East London. We were weak in Natal because the ANC was very strong there; we were weak in PE [Port Elizabeth], weak in the Western Cape.

When we got to PE on our tour in 1960, you could only whisper that you were there from PAC (laughter) because the ANC was so strong there. You were more afraid of the ANC than of the police in PE! It was like a religion, and religion was strong there too. Cape Town had no organization at all. We felt strongly that if we could build our strength in the Transvaal, then other things would follow.

By the time of the break. I had accepted the necessity of it and the fact that we weren't going to be able to capture the ANC. Our numbers were too small, and their methods were too successful.

One reason we couldn't make direct attacks on the banned leaders in the late 1950s was that we had to uphold the slogan of "We stand by our leaders" in the Treason Trial. You just couldn't attack them while that was going on.

Tambo felt that some opposition within Congress wasn't necessarily a bad thing. He didn't favor expelling the Africanists. All this time that the ANC was making these unwise moves in the 1950s, the Africanists were the only ones willing to speak up frankly and criticize. Once we were out, there was no one left inside to criticize or question. 


\section{GG: When you came to Johannesburg in late 1954 were your ideas any different than they had been in 1949 ? Had you rejected anything, e.g. from Lembede's philosophy, or added anything?}

RMS: No, I hadn't rejected anything. But I was hesitant to draw attention to myself as a critic of the ANC.

\section{GG: Can you trace the development of your own attitude towards personal involvement in politics?}

RMS: At the time I first came to Johannesburg, I still didn't see myself as an activist particularly, not of the Leballo-type anyway. I saw myself more as an intellectual who could help back up this movement and give it some theoretical strength. $\mathrm{P} \mathrm{K}$ and his group were "mainly emotional" in their nationalism; they needed firmer theory, more "academic" grounding. The articles that were appearing in the Africanist were a bit wild and diffuse, without much educational value. I felt that in at least every issue there should be one educational article, explaining the nature of the struggle to our people. So I was offered the editorship by P K and I was glad to take it up. I saw this as a way I could make my contribution, and also stay behind the scenes. But as soon as I became the editor, naturally the critics singled me out for attack. I became openly identified as an Africanist. I was never hesitant to take part, but unlike P K, I believed we should build our strength before inviting such open attack. I wasn't hesitant to participate. I was so very critical of the ANC, and believed so strongly in what we stood for.

\section{GG: I've been told that Leballo thought your family life held you back from full-time political work.}

RMS: No. Leballo would say this because we have different views of our wives. Zeph Mothopeng and I believed in treating our wives like other human beings, devoting time to them. Leballo believed his wife was just there to feed him, mind the children, etc. He gave every minute of his time to politics. I can believe that $\mathrm{P} \mathrm{K}$ spoke about "petticoat government."

I can remember in my days at Fort Hare Pitje and I considered this problem, and we took a vow that we would never marry because it would interfere with fulfilling our political tasks. Pitje was the first to break that vow! (laughter) My family life didn't conflict, but my job sometimes did. When these stay-at-homes were called, what could I do? The professors and students were there waiting for me, but naturally I couldn't be seen boarding the train in Mofolo. So l'd always have to make up some excuse of why I couldn't go to work or couldn't stay home. 


\section{GG: Is it true you favored opening membership in PAC to poorer Indians?}

RMS: This is true, but the others just wouldn't accept it. There were a lot of very poor Indian workers. They didn't come to South Africa of their own free will, they have no other home, they were themselves exploited, and there was no way in which they exploited Africans, unlike the Indian merchant class. The merchant class is prejudiced against Africans, and they are oppressors. Of course, we considered the coloureds as Africans. A B [Ngcobo] was so strongly against this thing of including Indians!

\section{GG: Hypothetically speaking, if PAC had come to power and then found that Indians persisted in preserving their own ethnic subculture instead of identifying with Africans, what would you have done?}

RMS: I wouldn't have been bothered by this, because I know that such changes take time. People would have been allowed their own customs, foods, and so forth. But we would have legislated against all racial discrimination - in housing, schools, everywhere. Eventually barriers would break down, with children going to school together and people living together. There would be "black spots" in white areas at first, and gradually merging would take place. Some Africans would move to Hillbrow; "Benjie would move to Soweto" (laughter). Of course there would be people who would cling to their prejudices. We would have to be patient.

I think [President Richard] Nixon is right in saying that children shouldn't be bused to force integration. This is going too far. You couldn't pass a law that a white man, for example, had to carry Africans in his car. You would, I think, at first also have to allow whites to maintain exclusive clubs if they wanted to. It would all take time. But you would immediately do away with all discriminatory laws. I am critical of what the Kenyans have done to the Asians there. If we had succeeded in bringing change I know we would have found, even in the first generation of Indians and whites, that there were people willing to come in with us wholeheartedly. We would have accepted them fully, as equals, as Africans with us. We would have "absorbed" them immediately. Others would come in more gradually.

\section{GG: To what extent is it true that PAC believed in violence or rejected non-violence?}

RMS: We didn't have any faith in non-violence, passive resistance, because the penalties had become too high. People were unwilling to engage in it, and it was no longer a useful technique. We did, however, believe in the potential power of massive 
“non-collaboration." Philosophically, we didn't hold to nonviolence. Is it [W E B] DuBois who said that there are three types of beliefs about violence? One is the Communist one, that no change can be accomplished without violence. The second is the pacifists' view that violence is never justified, no matter what. And the third, which was our view, was that violence might sometimes be necessary and couldn't be ruled out altogether. I didn't think in 1960 that we were in any position to launch violence, or that our people were prepared for it.

Passive resistance, we felt, could only succeed in more advanced "modern" countries, where demonstrations have been shown to bring results. In the US, for instance, I am critical of black radicals who have gone beyond the use of nonviolent methods. After all, protest is legal in the United States, and brings results. Why go beyond it? This isn't justified. But in South Africa, the use of passive resistance has been ruled out by the harshness of the laws against it. Students can't even stage a march without being penalized. Other means then become legitimate. I think I came to this conclusion only after going to prison.

It is not true to say that PAC promoted violence. We always stressed non-violence. We urged the police not to provoke violence by mumbling orders like "disperse in three minutes." Philosophically, we were not in favor of taking lives. We thought we could win by means that fell short of this.

\section{GG: When you said "we are ready to die for our freedom, but we are not yet ready to kill.” Did you mean not ready philosophically, or did this have the double meaning of "we do not yet possess the means of killing"?}

RMS: (Laughter) I know what you mean. I think I meant philosophically we weren't ready. We knew if there was violence it would only work against our cause. We believed that if we followed our plan, with the leaders in front, with sincerity, conviction, and strength, that the power of our example would be enough to mobilize the masses to action, to non-collaboration. [He acknowledged that the distinction between non-violence and non-collaboration was vague here, but we didn't pursue it.]

We believed that Africans could eventually succeed if they could break their psychological dependence on whites and non-African leadership. An example of African dependence on whites was one incident at Newclare when there was a women's demonstration against passes. We went there to try to persuade the police to grant bail for the women. Because we were Africans, the police just told us to voetsek [scram]. Then a certain white arrived on the scene, a man named Vincent Swart. He had started some small organization for African rights. Because he was white, the police agreed to talk to him, and naturally the 
friends and relatives of the women there just "flocked" to this man, pleading with him to help with bail.

We always opposed the participation of whites in any kind of action because we wanted to get the point across to our people that by their own efforts - and by these alone - change could be brought about. It was a psychological thing. When the pass laws actually were suspended and Africans had the sensation for those few days of not living in fear, we knew this would have a big psychological impact. People could see this had been done solely by African effort. Of course, I wasn't allowed to see newspapers during this time, so I wasn't able to follow developments closely. I did know there was undisciplined violence in the Transvaal. This was because the leaders were locked up.

\section{GG: What did you say to young men who demanded they be given a chance to fight the whites?}

RMS: This question never really came up, because right from the beginning we had promised action, we had told people that passes were to be the target, the leaders were going to be in front, and that this was how we were going to do it. This would be sufficient to bring us victory. We always stressed publicly that we were non-violent. After all, we had a responsibility to protect our followers from the consequences of possible violence, retaliation from the authorities. I myself never favored the idea of anyone being killed. I sincerely believed that determined non-collaboration could do the job, since the whole system, the whole economy, rests on the cooperation of our people. In prison I revised my views in that regard, however. Now that the penalties, even for passive resistance, are so high, up to three years, we can no longer ask our people to engage in this kind of action. The return is too small.

We believed at the time of our campaign that a determined lead from us would bring success. Ordinary Africans - like Madzunya's followers - didn't believe that we were prepared to suffer. We thought that, just as in the ANC where the people were willing to follow the leaders almost blindly, in our case they would also follow when we had given the example. The government was always hammering on this point - that the big leaders called people into action, then let them go to jail and suffer while they stayed outside "riding around in big cars."

\section{GG: Were there ever divisions in the National Working Committee over matters of policy, for example, over the decision to launch?}

RMS: No, everyone was in agreement over the launching. 


\section{GG: There are various theories about the launching. One theory is [Jordan] Ngubane's, that you were pressured into it by the others.}

RMS: I have read Ngubane's book [An African explains Apartheid], and that man has some very strange ideas. What he says is not true on this. Ngubane made us believe that he was with us and he had offered to get our three circulars printed for us in Durban, at an Indian press there. We just had no money, and so we agreed. The first leaflet was the alert, the second was the one telling people to save food, save money; then the last one. Our original plan was to launch in January, as soon as we got back from our tour of the Cape. I hadn't gone back to my job at Wits because I expected the launching to be soon. Ngubane had promised to have the circulars ready. I don't exactly recall the sequence of events. P K and J D [Nyaose] and I went to Durban to see to this printing, before we set out on the tour of the Cape. We met with Ngubane. A B [Ngcobo] wasn't there because he and Ngubane weren't on speaking terms. We asked Ngubane why these things hadn't been sent to us. He took us to meet the Indian editor of his paper [Indian Opinion], I don't recall his name, but it wasn't Manilal Gandhi. It was funny, us all sitting there when we were supposed to be so anti-Indian! (laughter) We had a long discussion, and we tried to press him with the seriousness of our intentions. Ngubane wasn't convinced by our arguments. We left, and later I wired him to urge him to send the circulars. He replied with a long letter saying he just couldn't provide them.

This was really our undoing. There was no going back. I told Ngubane we were going ahead whether we had the leaflets or not. Ngubane's letter said he thought the campaign was unwise. About this time I also had a letter from A P saying the same thing.

\section{GG: Was Ngubane in touch with Mda?}

RMS: I think so, but I'm not certain. So we proceeded with our tour. I was very impressed with our following in Cape Town. I knew Cape Town would respond well to the call. You had the men there living in bachelor quarters. Some reliable source said the ratio of men to women there was 25 to 1 . People's grievances were very strong in Cape Town. I also knew we could be sure of Sharpeville.

\section{GG: Why?}

RMS: People there had some local grievances, especially against the location superintendent. The leaders there had assured me that the people were ready; we had nothing to worry about there. They could have launched with success in January, even though demonstrations were forbidden there. Ngubane really let us down. Boys 
had come up from Cape Town to get the circulars, and we just had to send them home empty-handed. We gave them a sample and told them to make their own. We sent a model to East London and told them to make their own, also Port Elizabeth.

\section{GG: How did you decide on the date for the launching?}

RMS: The main thing was that the ANC was about to launch its own pass campaign. We knew this would be another three-day affair, the people's energies would be exhausted, and we would be unable to act. So we had to launch first; that was the main thing. We would have launched earlier if we had gotten the circulars. We had promised the people that they were going to get action.

The response was poor in Johannesburg the day of the launching because of the lack of the leaflets. Also, Johannesburg has often lacked militancy, partly because the city administration there has always been relatively progressive. Africans in Johannesburg are less idealistic, more materially-oriented also.

\section{GG: If the launching had resulted in widespread chaos and violence. Do you think progress would have been made?}

RMS: No, I was against this. That is why I told the police not to provoke the people by giving impossible orders, like disperse in three minutes. Privately, on the Cape tour and at other times in preparing for the campaign, I had told leaders that if the police ordered crowds to disperse, then they should be ordered by the leaders to disperse.

\section{GG: Do you think the leaders in Cape Town acted correctly, then, at the time of the big march?}

RMS: Yes, I do. They were carrying out the orders that I had given. Naturally I hadn't made it public that if police told us to disperse, we were going to disperse. That would have undermined the people's confidence. But I had ordered this privately. In Cape Town, had I been there, I would have done the same thing.

Perhaps Ngubane acted the way he did because he was resentful that we had rejected his advice. Something made him vindictive, and I think that is why he printed in his book that thing about my appeal. This was unfair. He wasn't in a position to appreciate the circumstances. The police had divided us into two groups: the followers and the leaders, who were tried separately in a batch of 22. Some of the men included in thisleaders' group-peoplelike Lennox Mlonzi and Rosette Ndziba - objected to their being included as leaders. They wanted to be in the other group. They felt that with us their sentences were going to be too heavy. So they

PINS [Psychology in Society] 50, 2016|72 
wanted to appeal; perhaps a majority in our group wanted to. Then I consulted Joe Slovo, and he advised me that it would be impossible for only part of the group to appeal, since we had all been tried together. It was all or nothing, So I agreed, but only on condition that the appeal was on the merits of the case, not merely against the severity of the sentences. I had been in favor originally of dividing us into leaders and non-leaders because I had hoped they would only sentence the leaders and let the rest go free. They would have been able to carry on the campaign outside.

\section{GG: Do you think P K [Leballo] or the others misled you about the preparedness of the people?}

RMS: No. P K and I always worked very closely together, and I knew everything he knew. There was no question of my being deceived. Everyone knew that PK always exaggerated. "He would add a naught to every figure." If there were 25 people at a meeting, P K would come and tell you there were 250. But we always knew to allow for this (laughter).

\section{GG: What was the basic strategy of the pass campaign? How did you envision the "unfolding" stages?}

RMS: By filling the jails we believed we could bring the economy to a halt. If the defiance had gone on and on, eventually they would have been forced to negotiate with us. The women were told to stay home, to keep things going while the men - the backbone of the economy - went to jail. Eventually we thought the women would join too. We believed the people were ready, if a clear lead was given. They would see that we were ready to give up jobs - good jobs, too - and they would be convinced by our example.

\section{GG: If it had come to negotiations, what would you have demanded?}

RMS: Firstly, the things we had specified in our propaganda - the abolition of the pass laws and the minimum wage of one $£$ a day. The whole system of control is built on the pass laws, so this is crucial.

\section{Gail Gerhart (GG): what would have come next?}

Robert Mangaliso Sobukwe (RMS): Well, probably the next thing would have been the vote. I was prepared to acknowledge that this would take time. I would actually have accepted a qualified franchise, as long as it was equal for all races. This would have been hard for them, perhaps impossible, because it would have disqualified some white voters. But the vote would have been next. 


\section{GG: Do you think the high morale of the working committee ever clouded anyone's evaluation of political reality?}

RMS: I wouldn't say so. Except for P K, they were a rather "cautious" lot. It was a "strange" group. They were always raising reasons why something or other couldn't be done. P K was always optimistic about success, but the rest were cautious.

\section{GG: In planning the campaign, did you discuss any lessons of the 1952 defiance campaign?}

RMS: Yes, definitely, at length. We felt the Defiance Campaign had failed because the leaders had let the people down by calling the thing off when the going got rough for them personally. They engaged lawyers, particularly [ANC president Dr James] Moroka. And we saw that these new laws - the Public Safety Act, etc. - were a threat to their interests. The campaign was still going strong, and the people were prepared to continue, but it was the leaders who backed down. That was the lesson of the Defiance Campaign - failure of the leaders. So we knew we weren't going to repeat this error; that is why we asserted the slogan of "no bail, no defense, no fine" - to convince the people that we were serious this time.

\section{GG: Did you or your men ever refer to the proposed action as "revolution" in the literal sense?}

RMS: [No direct answer to this. He went off on something else, and I didn't return to the question.]

\section{GG: Was there any feeling that the government might be a false front, apparently strong but actually weak, ready to fold like the Belgians in the Congo?}

RMS: No, not among the leadership. But remember when the campaign was launched, there was massive support in Cape Town and then rioting in Johannesburg. The police were paralyzed. They just didn't know what to do for awhile. The pass laws were suspended.

\section{GG: Who did you consider the strongest members of the Working Committee?}

RMS: The hardest worker was always P K For all his weaknesses, this was one man I always liked. One had to admire his energy, his ability. I had confidence in him, and I relied on him heavily. He was always ready to sacrifice everything he had for our movement. 
More than anyone else, he was always willing to put the party's interests above his own.

\section{GG: Do you think he ever fancied that he should be president instead of you?}

RMS: No. I'm sure he didn't. P K is not such a highly educated man, not as much as others in our group. He knew these limits. He was very happy to be secretary; he never saw himself as number one. Nana [Mahomo] hated him though. Nana even opposed his becoming secretary. One of P K's weaknesses was a tendency to try to build up a personal following. The others criticized him for this. There was conflict whenever Nana was around.

P K also tended to always pick out one person that he didn't like. In the Working Committee he picked Ngendane as his target. If Ngendane said something was white, "P K would feel constrained to argue that it was black." Ngendane was a "playboy," a fancy dresser. He often was absent from Working Committee meetings, or he would come and have his girlfriend waiting outside. It was only later when I got to know him much better in prison that I myself began to appreciate the quality of Ngendane's mind, and the sincerity of his devotion to our cause.

One of Leballo's strengths was that there could never be any doubt that he was prepared to suffer, prepared to go to jail. He was a "fire-eater." He raised money and he never spent a penny on himself. I had to give money to "the wife" because P K wouldn't give her money for food. He put everything he had into the organization. This is why I can hardly believe the stories of P K "squandering money" on the outside, because he never did that when I knew him.

One of his weaknesses is that in any group he will pick one person to attack, one person that he doesn't like, like Ngendane. If there are three people, he'll join with one against the third. If there are five people, he'll get three with him against the other one. In the National Executive he picked out Nyaose as the one he didn't like.

\section{GG: Why is he like that?}

RMS: P K by nature is "an oppositionist." He's always got to be in opposition to something. He'd never be a good member of a government. P K was expelled various times from the ANC because of being this way. I myself didn't want to be expelled. Although I was known as an Africanist. I was merely regarded as someone on the "right wing" of the ANC.

In the PAC, I drafted many of the letters that went out over P K's name. 


\section{GG: Did you also write the pieces that appeared in The Africanist over his name?}

RMS: I don't recall ever doing this. He wrote those pieces himself. There was only once I can recall when I got angry at him for overstepping without consulting me. He put something in The Africanist about how A K Harden had written to denounce a certain South African "half caste" named Michael Hommel who had been exposed in Ghana as a spy. P K put this into The Africanist without showing me first, and I had to take him to task for using the term "half caste." Since we were supposedly accepting coloureds as Africans, naturally we couldn't use such derogatory terms to refer to them.

$\mathrm{PK}$ and I always worked very well together. But another one of his weaknesses was that he could never be trusted to keep a secret. The others always tried to hide things from him for the sake of secrecy.

Nana was a backroom boy, not a good platform man. He did a good job of organizing in Cape Town, organizing the Task Forces there, one for each area of the townships. These boys did the distribution of leaflets and jobs like that.

Nyaose was not a politician; he was just a "hard working trade unionist." Philosophically, he wasn't part of our Africanist movement, but his union - the Bakers - had opposed Communist leadership.

We nationalists had virtually written off trade unions. Their administration was so weak, and they were so easily dominated by Communists. African unions were mere puppets. There were only a few exceptions - Nyaose's Bakers Union, which was very well run and had actually negotiated and won concessions from employers, like a real union; and Lucy Mvubelo's Women's Garment Workers Union. Not the men's Garment Workers - they were Communist-led. Only the women were strong and independent, African-led.

\section{GG: Is it true that Nyaose opposed the launching of the campaign?}

RMS: No, this isn't true. In fact he even exaggerated to me the strength of his own supporters, their numbers. He wouldn't have done this if he opposed the launching.

[Peter] Molotsi was a "hard worker," not lazy, but he had a tendency to want to discuss things at great length on an academic plane. In abstractions. He had a very sharp tongue, both he and Z B [Molete]. Both were good "platform men."

Mahomo wasn't such a good platform man, but whenever he came up from Cape Town 
he always brought some good ideas, like the idea of the task forces. That was Nana's idea. It was our way of using the "tsotsi element."

The best brains in the NWC [national working committee] were Rocks [Peter Raboroko], $Z \mathrm{~B}$ and Molotsi. They were the idea-men, the "original" thinkers. Rocks had the weakness of not being able to resist the bottle, but he is a "brilliant" man. Z B is also highly intelligent, but "a little lazy."

\section{GG: How important were the executive members who lived outside the Transvaal?}

RMS: These men were quite far removed from the action. We sent them reports and copies of statements, but naturally they were quite cut off. I knew them less well. We only met together once. We had agreed that we would meet at least once a year, but in the end we were only able to meet once.

Morley Nkosi "never took politics seriously," even in South Africa. He was working for some company then. He was supposed to launch and we were very angry when he didn't. He became enemies with Ellen Molapo when they were trying to operate after the emergency. If Nkosi wants to be helpful now, he should look around and not wait. Ngendane and [Zeph] Mothopeng are in need of help - they have no prospects of employment. [John Nyati] Pokela is doing 30 years on Robben Island, and his family needs help.

Ellen Molapo convinced us that women were capable of understanding our philosophy. Lucy Mvubelo also convinced us; she was a strong figure. She and her union sided with the ICFTU [International Confederation of Free Trade Unions] against the other trade union federation in Africa - the leftist one. But in general we knew that women were more conservative politically than men.

\section{GG: After the breakaway, did tambo or others try to bring about a reconciliation?}

RMS: Yes, there was some effort, but not much.

\section{GG: Do you think the common man in the street understood your explanation of nonracialism?}

RMS: [Answer vague here, but I think the gist was "no."] There was nothing one could say that could really cut through the fact that most people were simply anti-white. I wrote somewhere that our people don't hate the sjambok; naturally they hate 
the man who wields it, because he is an oppressor. This summed up how most people feel.

But I always pointed out whenever I got the chance that when foreign white teams came to play against South Africa, we always rooted for them. Therefore we couldn't say that we were against all whites everywhere as such, only whites in South Africa. It wasn't really a question of skin color; it was a question of who is the oppressor.

The strength of anti-white sentiment was a major factor in our calculations. We knew that the vast majority of Africans are simply anti-white; the tsotsis and right on up, everyone. Whenever the press called us anti-white, we felt this was to our advantage.

\section{GG: You were actually glad?}

RMS: Yes (laughter). This was our surest way of getting the people with us. I didn't say such things openly, of course. That was P K's role, to play to these sentiments. He had no hesitation about doing it.

Another weakness of $\mathrm{P} \mathrm{K}$ is that as soon as he sees his name in the newspaper, he tends to get carried away, and to do something else to get his name back in the paper again.

All the papers were hostile except The World. Even Benjie [Pogrund at the Rand Daily Mail] sometimes printed things against us.

Intellectually, I didn't believe in drawing the conflict along strict color lines. We were opposing a racially exclusive policy, and I realized the contradiction of preaching the same line ourselves. But we were not the oppressors. I actually believed in seeing it more from a Marxist point of view in terms of the material interests that were at stake. I couldn't sell this fully to my colleagues. People from Natal were especially adamant about any matter concerning Indians. But I was conscious of the fact that we had to come up with a way of expressing our position that would be acceptable to varying types of people. We worked very hard to do this.

\section{GG: Were you influenced by the views of Pogrund and [Patrick] Duncan?}

RMS: Yes, I was. But I also knew that ordinary Africans, the people in the streets, the people who attended our conferences, were motivated plainly and simply by "naked anti-white feeling." "All of our people are anti-white, anti-Indian, even anti-coloured. Our 
people are anti-everything." Our people hate the whites, and there is no point in denying it. We had to attract these people to us; of course we had to take their sentiments into account. I couldn't say this kind of thing publicly, of course.

\section{GG: Did PAC ever consider trying to ally with any of the separatist churches?}

RMS: We did think of them as our allies, definitely. We saw them as recruiting grounds for us.

\section{GG: How?}

RMS: We approached the leaders. But they were always hostile to people who were still members of non-separatist churches. Occasionally we would get opportunities to address congregations. P K addressed a few congregations (of the African Methodist Episcopal [AME]?) Bishop [Walter M] Dimba was with us, and so was Rev [Nimrod] Tantsi, though I don't know if he ever actually became a PAC member. The feeling in these churches was very anti-white; it was the whole basis of their existence.

[We laughed over the story of the conference where some Basotho "Russians" (gang members / tsotsis) were told by ANC leaders to rough up the Africanists, then someone slipped them the word that the Africanists were the ones who wanted to "drive the white man into the sea," and they refused to attack.]

\section{Gail Gerhart (GG): To which groups in the African population did you expect PAC to have the most appeal?}

Robert Mangaliso Sobukwe (RMS): "Students and intellectuals." But actually we didn't think in terms of appealing to particular groups. We felt our appeal was to everyone. And we didn't believe that there was a true African middle class, or true classes at all among Africans. All Africans have to carry passes, live together in the townships, and so on, and this puts them on the same level.

\section{GG: Did PAC particularly attract tsotsis?}

RMS: Yes, this was true. They are the most bitterly anti-white element, anti-everything, especially in Johannesburg. In Johannesburg you do have classes in a way, and many Africans are quite "bourgeois," materialistic. The tsotsis aren't, and there is friction between them and the bourgeois element. We recruited entire gangs by getting together with their leaders and persuading them to work for us instead of fighting each other. They were some of our strongest supporters in the Transvaal. 
Anyone in the PAC leadership could walk through the townships at midnight, and no tsotsi would lift a finger against him. Ngendane once nearly got himself in trouble, though, because he was such a sharp dresser. One night some tsotsis stopped him and roughed him up a little. They didn't beat him up, they just warned him that Sobukwe had said that the high were going to be made low and vice versa. They didn't say this in words; they gestured with their hands, showing that high was going to be low (laughter). Their concept of politics wasn't very sophisticated, but they had grasped basically what we stood for.

Of course, we wanted to appeal to workers, but every African is a worker, more or less. We couldn't hope to use trade unions to any great extent, because they have never been strong. We hoped to appeal to workers directly, as individuals rather than union members. Port Elizabeth was always a stronger trade union center than the Reef.

\section{GG: How strong was Fofatusa [Federation of Free African Trade Unions of SA]?}

RMS: It was in the same position as PAC - very new. The Bakers and the Women's Garment Workers were the strongest. We didn't use Fofatusa directly; we didn't address its meetings, for example. We just knew that the members would join as individuals. Whenever we spoke to Fofatusa union officials, we realized that their main concern was benefits - of a trade union type - for workers, though they saw the importance of politics.

\section{GG: Why did you assert the slogan of "independence in 1963"?}

RMS: (Laughter) This rightly could be called "propaganda." Of course none of us believed this was really possible. This was simply an effort to hold out to people the prospect, the hope, of a reward for their efforts. We wanted people to have a goal, something they would achieve if they followed us. We figured that by the time 1963 actually came, we would by then have achieved enough that the people would be completely with us. The ANC would be eliminated altogether. We wanted to just do in the ANC completely, by the sheer force of our numbers. They would be swept off the map by us. We would start by trying to convert their members to our side, but eventually we would be enrolling completely new people, more members than they had ever had, because we would attract people who had been "uncommitted." The slogan was simply propaganda. 


\section{GG: Do you think most people - e.g. the tsotsis - grasped the idea of Panafricanism? Of a United States of Africa? Was this all propaganda, or did you believe in it?}

RMS: Oh yes, we sincerely believe(d) in this. And even schoolboys - and many tsotsis were schoolboys - understood perfectly well the idea that Africa was one. This wasn't beyond them, and it was very appealing.

\section{GG: Is it true that you felt anything Nkrumah said was "the gospel"?}

RMS: Yes, in a way we did. Nkrumah was tremendously important to us. He was the first leader of an African state, a modern African state. Just at this time you had [Roy] Welensky attacking [Hastings Kamuzu] Banda, saying he couldn't even run a municipal office. We were always being reminded that Ethiopia and Liberia were the least developed countries in Africa, because Africans were incapable of doing anything for themselves without European guidance. There was a constant degradation of our people in this way, and naturally we in South Africa were affected psychologically by this.

Then Nkrumah came and showed that Africans could run a "modern" state, not like Ethiopia or Liberia. Anything Nkrumah said naturally seemed like the ultimate wisdom. Our real gospel actually was George Padmore's book, Pan-Africanism or Communism? We got this when it first came out - I don't recall just when. A few copies (or one?) was passed around until it was dog-eared. It was "compulsory reading" for the Africanists. No other book was comparable in influence.

At that stage we knew that we couldn't count on other African countries for material aid. We knew they were weak, that they couldn't give military help. But we looked to them for inspiration.

\section{GG: What was the origin of PAC's connection with the BCP [Basutoland Congress Party]?}

RMS: It was my friendship with [Ntsu] Mokhehle, dating back to when we were together at Fort Hare. He began the BCP along the lines of the original Youth League. I was invited to speak at their opening conference in 1957, and again in 1958. 


\section{GG: Was there anything in the claim made by some that ANC was more an Nguni party and that PAC spoke more for the Sothos, or attracted the Sothos more?}

RMS: No, this isn't true. How would one explain the allegiance of Cape Town to PAC? There were many non-Nguni leaders in the ANC - Moses Kotane, J. B Marks, Elias Moretsele weren't Ngunis.

\section{GG: Leballo told me that one reason Sharpeville was so militant was because it was nearly all sotho and he could speak to them in the vernacular and they looked to him as one of them.}

RMS: That may be true, but one couldn't generalize. It would even be difficult to say to which group I myself belong. My father's father was a southern Sotho who moved from Basutoland into the Transkei. My mother was a Xhosa. My wife - I found out after marrying her - is a Zulu. My children have schooled in Lesotho and they speak Sotho best.

Tribalism is our "enemy number one."

We had no regard for this factor when we chose our National Executive or our leadership at any level. Oddly enough, intellectuals in South Africa tend to make more of the tribal issue than do ordinary Africans. An ordinary man accepts anyone as his equal and doesn't care where he comes from. Intellectuals look for ways to use the tribal factor to their own advantage. They play it up. And of course the government wants to play it up too, to manipulate tribal feelings for their own ends. People are susceptible to this, unfortunately. But ordinary people will always accept a leader and judge him by his ideas, not his tribe. Take the example of an outsider like Clements Kadalie.

It is also worth noting that quarrels are often most bitter, not between Nguni and Sotho, but between peoples who are most closely related - the Zulu and the Xhosa, the Sotho and the Tswana. Whatever one may say about Nkrumah, one must give him credit on this question. Nkrumah wiped out tribalism in Ghana, consciously and thoroughly. [We agreed that Kenyatta seems to have missed his opportunity to do the same for Kenya.] 
I remember at the 1949 Bloemfontein conference that everyone spoke in his own language and there were no interpreters. But Xuma always used English. He refused to use Xhosa or to be identified in any way with one ethnic group. Intermarriage between tribes has always been the ideal for nationalists. If the PAC had come to power, we would have eliminated this problem of languages. English would be made the national language because it is most widely understood in Africa.

\section{GG: How was it decided that Molotsi and Mahomo would leave on the eve of the launching?}

RMS: I decided this; it was my idea. No one opposed it that I can recall. If $\mathrm{P} K \mathrm{~K}$ later claimed that he opposed it, he was probably just looking for ways to discredit them.

\section{GG: When you were in jail could you communicate with the outside at all?}

RMS: At first I could, but I never felt assured that my orders would get to the right people.

\section{GG: What was your reaction when you heard about Poqo?}

RMS: This thing was "undisciplined." No movement can succeed without discipline. I could see that once the leaders were in jail, things had gotten out of control. There was no way of guiding this (Poqo) thing; it was the "tsotsi element" taking over.

I don't think Leballo should have made the statement that PAC and Poqo were the same, because they weren't, really. Poqo had about the same relation to PAC that Mau Mau had to KANU. They weren't the same thing.

I had always known that we had people who believed in blowing up things, in sabotage. When we were organizing for the campaign, people came to me and asked for permission to derail trains and things like that. I told them no, that we could probably succeed without that. But I did think that at some later stage of the campaign we might have to do this, to hit at the economy by derailing trains that carried workers into Johannesburg, for example. But I myself took no part in this, I thought I could leave it to those people (who knew how to do it.) We never considered blowing up pylons. We didn't think there was any point in hitting any targets except the government itself - transport, perhaps "municipal buildings." We didn't believe in taking anyone's life. 


\section{Further notes on interview with Robert Sobukwe, August 8 and 9, 1970}

Sobukwe is a rather ordinary looking man, about 5'10", slightly stooped in his walk, energetic and jaunty. He chain-smoked through both our conversations. He has a warm laugh, a ready smile, a pleasant voice and eyes that light up - very small eyes with no lashes or brows. His speech is completely fluent; he rarely searches for words. Like A P Mda, he has a wide command of English idiom (Nana and P K "didn't hit it off"). He used the word "academic" several times to describe his own approach to analyzing problems. Has he perhaps picked up some things from his studies in prison that he now applies to things with hindsight? There was no point asking in the interview when it seemed likely that something was being given an ex post facto interpretation.

Talking about the tsotsis, he made a revealing statement to the effect that he never ever had doubted his own ability to convince any African of the rightness of his point of view. All he needed was a chance to talk to a person, e.g. any tsotsi. In effect he was saying he had such complete confidence in his own principles that he felt they were self-evident to anyone who would stop to give them consideration. This came up in the context of how he might have fared in the U.S. had his application for an exit permit been successful. He was saying that, in effect, he was confident of being able to win anyone's respect. He noted that the police in Kimberley "respected him" and that he was "respectful toward them."

He never expressed the sentiment "my life's work may be finished, but I've done what I could," nor did he say anything to the effect that the struggle still goes on and I'm part of it still. He made no summary statements about his own life as it stands at this point.

The second day we were parked near a path off the main road and two teenage boys passed, carrying sticks, wearing blankets, their faces painted white. He didn't know what tribe they were, but he said he remembered going through the same initiation process, with his face painted white. He remarked they had been in this condition for some time because their hair had already grown out from being shaved.

The novel he is writing is not at all political. It draws characters from his childhood in Graaff-Reinet. The people in it are partly urban, not really still tribal; they are confused about their lives. The book has no moral. If it has any point, it is summarized by a saying in Xhosa that you must "sleep on your wounds". If you are hurting, never let anyone see it. 
The University of Wisconsin has offered to send him linguistics books. He is going to write and ask if there is any way he can do the degree and be examined by an external examiner appointed by them. He was amazed that Roosevelt University was prepared to pay him \$2 000 just to lecture once a week. He didn't know that Roosevelt was a black school.

He thinks the police are leaving him alone more since the denial of the exit permit. He said if he ever left "it would be by the front door," though it would be easy enough to escape from Kimberley since it's so near the border. (Pogrund thinks the police are actually watching to see if he'll run). Our first day we were followed short distances by 2 traffic police cars, and I was questioned by a plainclothes man at my hotel.

A white friend in Kimberley took him a few days before to the nearby white resort of Riverton. Sobukwe went in as the "boy". But that's risky since he is easily recognized. At least every African in Kimberley recognizes him.

Veronica (his wife) has taken the denial of the exit permit very hard. She has even been sick, which he thinks is psychological. She was so excited about the chance of going that she knew the average temperature in Wisconsin was something like 50 degrees. Sobukwe said he never expected to get the permit.

Their two oldest children are in a boarding school in Lesotho in Form I (St. Agnes?) They have a woman Peace Corps teacher there in English. The twins are in Std 5 and 6, and they live with friends in Lesotho. They have lived with them for a long time. It is good that in Lesotho there is at least some contact with the outside world and a strong emphasis on learning English from native speakers.

Veronica had a job for about a month in Kimberley as a nurse. But their names were still so much in the papers that she was singled out there for different treatment and she didn't like it. The matron wouldn't give her any direct orders; she would give the orders through another person, right in her presence.

Pogrund and Raymond Tucker want to take the permit case to court, and argue that either the government must grant the permit or pay him a sum of money equivalent to what he would have been paid at Wisconsin and Roosevelt Universities. 